\title{
Effects of the flood regime on the body condition of fish of different trophic guilds in the Upper Paraná River floodplain, Brazil
}

\author{
Abujanra, F. ${ }^{\mathrm{a}, \mathrm{b} *}$, Agostinho, AA. ${ }^{\mathrm{a}}$ and Hahn, $N S{ }^{\mathrm{a}}$ \\ aPrograma de Pós-Graduação em Ecologia de Ambientes Aquáticos Continentais, \\ Núcleo de Pesquisas em Limnologia, Ictiologia e Aqüicultura, Departamento de Biologia, \\ Universidade Estadual de Maringá - UEM, \\ Av. Colombo, 5790, CEP 87020-900, Maringá, PR, Brazil \\ bLimnobios, Av. Pioneiro Alicio Arantes Campolina, 1223a, \\ CEP 87020-750, Maringá, PR, Brazil \\ *e-mail: fabujanra@yahoo.com.br
}

Received November 7, 2008 - Accepted March 3, 2009 - Distributed June 30, 2009

(With 3 figures)

\begin{abstract}
In this study, we evaluated the influence of various hydrological cycles on the feeding body condition of fish species of different trophic guilds in the Paraná River floodplain, as well as the impacts of upstream impoundments on fish conditions. Attributes of the river floods (duration, time of year, intensity, and variability in a given year) and the body condition, measured by the mean residuals of length-weight ratios, of the detritivorous, herbivorous, insectivorous, invertivores, omnivorous, piscivorous, and planktivorous species were evaluated. Fish were sampled during a period before (1986-1994) and after (2000-2004) the completion of filling of the Porto Primavera Reservoir, which is located upstream from the floodplain area under study. Three sub-basins in the floodplain were sampled: the Ivinheima River, which has no dams; the Paraná River, which has several dams; and the Baia River, which is influenced by the Paraná. A two-way ANOVA identified significant variations in mean body conditions for localities and for the hydrological cycles, and the interactions were also significant. The findings revealed that before the Porto Primavera Reservoir was filled, the body condition of the feeding guilds varied similarly in the three sub basins, but this pattern was not observed after filling was completed. However, in years with minor or no floods, the body condition was high, especially in the sub-basins influenced by Porto Primavera (Paraná and Baía). Pearson's and Spearman's correlations showed that most effects of the floods were unfavorable to the body condition of the guilds, except for the annual variation in water level, which aids herbivores in accessing allochthonous food resources. Detritivores were negatively affected by all flood attributes. A correlation between the relative stomach weight (mean residual of the ratio of total and stomach weights) and the body condition demonstrated the poor relationship between the amount of food intake and weight gain; insectivores were the exception, showing a significant negative correlation. Therefore, for this guild, there is evidence that their food sources during floods have low nutritional value. It is hypothesized that dry years lead to improvement in the nutritional quality of food resources, and that the water released from the upstream dam dilutes and removes these resources without providing new food inputs. This exacerbates the effects of floods on body conditions.
\end{abstract}

Keywords: condition factor, nutritional condition, flood pulses, floodplain, regulated rivers.

\section{Influência do regime de cheias na condição corporal de peixes de diferentes guildas troficas na planície de inundação do Alto Rio Paraná, Brazil}

\section{Resumo}

Nesse estudo, buscou-se avaliar a influência de diversos ciclos hidrológicos sobre a condição nutricional de peixes de diferentes categorias tróficas, na planície alagável do alto rio Paraná, bem como dos impactos de represamentos a montante, sobre esse processo. Para isso foram avaliados os atributos das cheias anuais (duração, época, intensidade, variabilidade) e a condição nutricional dos peixes, medida pelos resíduos médios da relação entre o peso e o comprimento de espécies detritívoras, herbívoras, insetívoras, invertívoras, onívoras, piscívoras e planctívoras. Os peixes foram coletados em período anterior (1986-1995) e posterior (2000-2004) ao represamento de Porto Primavera, a montante, em três subsistemas da planície alágável do alto rio Paraná, Ivinheima (sem controle por represamentos), Paraná (com represamentos) e Baía (influenciado pelo rio Paraná). Uma análise de variância (ANOVA bifatorial) revelou variações significantes na condição nutricional média dos peixes, tanto entre subsistemas e ciclos hidrológicos, como em suas interações. Os resultados evidenciaram que antes do represamento, as variações na condição nutricional dos peixes 
foram similares entre os subsistemas, divergindo no período subseqüente, e que em anos com cheias incipientes ou nulas a condição nutricional foi elevada, especialmente nos subsistemas influenciados pelo represamento a montante. As correlações de Pearson e Spearman revelaram que, pelo menos parte dos atributos das cheias foram adversos para os peixes de diferentes categorias tróficas, exceto a variabilidade anual dos níveis fluviométricos, que possibilitou às espécies herbívoras o acesso periódico a fontes de alimento externas. As espécies detritívoras foram afetadas negativamente por todos os atributos da cheia. As mesmas correlações realizadas entre o peso relativo do estômago (resíduo médio da relação peso do estomago-peso total) e a condição nutricional demonstraram ausência de relação entre a quantidade de alimento ingerida e o ganho de peso, exceto para as espécies insetívoras, para as quais a correlação mostrou-se significativamente negativa, sugerindo ser sua fonte de recurso durante as cheias de menor valor nutricional. Postula-se que os anos secos permitem uma melhoria na qualidade nutricional dos recursos alimentares e que os efluentes de barragem promovem a diluição e o arraste desses recursos, sem que se promovam novos aportes, potencializando o efeito das cheias sobre a condição nutricional dos peixes, independente de seus hábitos alimentares.

Palavras-chave: fator de condição, condição nutricional, pulsos de cheias, planície alagável, rios regulados.

\section{Introduction}

The "river-floodplain" systems in tropical latitudes provide a great heterogeneity of habitats and high biodiversity (Lowe-McConnell, 1999). These characteristics are highly related to the hydrological regime, with alternate flood and dry periods. These pulses have been considered as key factors in the biotic integrity (Agostinho et al., 2004a), and are responsible for the proper structuring and functioning of these areas. The processes by which the flood regime affects the functioning of these environments have been thoroughly discussed by Junk (1989), Neiff (1990), and Junk and Wantzen (2004).

In the neotropical region, some of the most prominent factors making the flood pulses highly important for the integrity of the floodplains are: changes in limnological characteristics, balance of production and respiration processes, patterns of nutrient cycling (Thomaz et al., 2004), structuring of the aquatic communities (Junk, 1980), and the increase in availability of food resources for the fish (Junk, 1980; Lowe-McConnell, 1999; Marçal-Simabuku and Peret, 2002). Junk (1980) added that the changes in hydrological conditions affect not only the quantity, but also the quality of available foods. In this way, the availability of food resources for the ichthyofauna, as well as the nutritional value and digestibility of food, are directly and indirectly related to the river dynamics.

In the Paraná River basin, as in many other drainage basins worldwide, these systems have been profoundly altered by the regulation of discharge by reservoirs upstream, which affects the intensity, duration, and timing of the floods, and consequently affects the availability of food (Agostinho et al., 2004a). Because of the importance of the integrity of floodplain areas to the maintenance of biological diversity, considerable efforts have been expended to understand the mechanisms through which this regulation affects ecosystem processes, and the conservation of the biota in particular.

Several studies of the effect of annual variation in water level on the diet of fish in this region have been carried out (Almeida et al., 1997; Hahn et al., 2004; Russo, 2004; Luz-Agostinho et al., 2008). However, studies on the effects of the inter-annual variation of the flood re-

gime (involving periods before and after the construction of the Porto Primavera Reservoir) on features related to the intensity of food intake and the body condition of the fish species have been accomplished only for piscivorous fish (Luz-Agostinho et al., 2009).

Based on the assumption that the flood pulses alter the composition, quantity, and quality of food resources available to the fish, and the assumption that the characteristics of the water released from the reservoirs undergoes changes related to the transport and sedimentation processes, it is postulated that inter-annual variations in the attributes of the floods (duration, time of year, intensity, and variability) affect the body conditions of fish differently, according to their food habits and the particular environment, independently of the amount of food ingested. The evaluation and discussion of this hypothesis is the object of this study.

\section{Materials and Methods}

The data on the hydrological cycles of the Ivinheima and Paraná rivers were provided by the Hydrology Department of Itaipu Binacional. The data were obtained at the hydrological stations located at Porto Sumeca and Porto São José.

The annual hydrographic data, considered as attributes of the flood regime, were: duration of floods (\% of the number of days with water levels above the long-term mean); time of year (temporal displacement, in two-week periods, of the first month of each flood, according to historical records; Agostinho et al., 2007); intensity (maximum level and annual mean); mean level in flood season (November to May; Thomaz et al., 2004) and variability of the levels (coefficient of variation, calculated based on daily records).

The data for river levels of the Baía River, whose fish assemblage is also analyzed in this study, were surrogated using the Paraná River level because their variation was similar to the Baía, which has a nearby and parallel course, and has surface contact with the Baía during major floods (Luz-Agostinho et al., 2009). 
Fish collections were made on the Upper Paraná River floodplain on a monthly basis from October 1986 through September 1987 (86-87), October 1987 through September 1988 (87-88), March 1992 through February 1993 (92-93); every two months from March 1994 through February 1995 (94-95); and every three months from February through November in the years 2000, 2001, 2002 and 2004. The collections were made at many sampling stations located in floodplain lakes, channels, and river environments, and were distributed among the Ivinheima, Baía, and Paraná rivers (Figure 1).

The fish were grouped according to feeding regimes in six trophic guilds (detritivores, herbivores, insectivores, invertivores, omnivores, piscivores, and planktivores), based on data compiled by different investigators (Hahn et al., 2004; Russo, 2004) for the Upper Paraná floodplain (Table 1).

Stationary and trawl nets were used for the fish catches, with a standardized effort exerted for each type of fishing gear. After the fish were removed from the nets, they were identified, measured, weighed, and eviscerated for identification of the sex and to obtain the stomach weight.

The mean body condition was calculated based on the mean values of the standardized residuals, gener- ated by the regressions between the logarithms of total weight (Wt) and standard length (Ls), by species. When males and females presented different values, tested by ANOVA, residuals for each sex were obtained using different equations. The significance levels of the differences in the means for the sub-basins, periods, and their interactions were assessed by analyses of variance (bifactorial ANOVA). The significance level adopted for all analyses was $\mathrm{p}<0.05$.

The correlation between the attributes of the floods and the changes in body condition was assessed by Pearson's (linear) and Spearman's (nonlinear) correlations, using the program Statistic, v. 7.0.

\section{Results}

\subsection{Hydrological regime}

The daily variations in the levels of the Ivinheima and Paraná rivers in the assessed periods from October 1985 through September 2005 showed that in both rivers, the floods were most intense and pronounced during the 1992-93 period (Figure 2), and were minor during the 1999-2000 hydrological cycle.

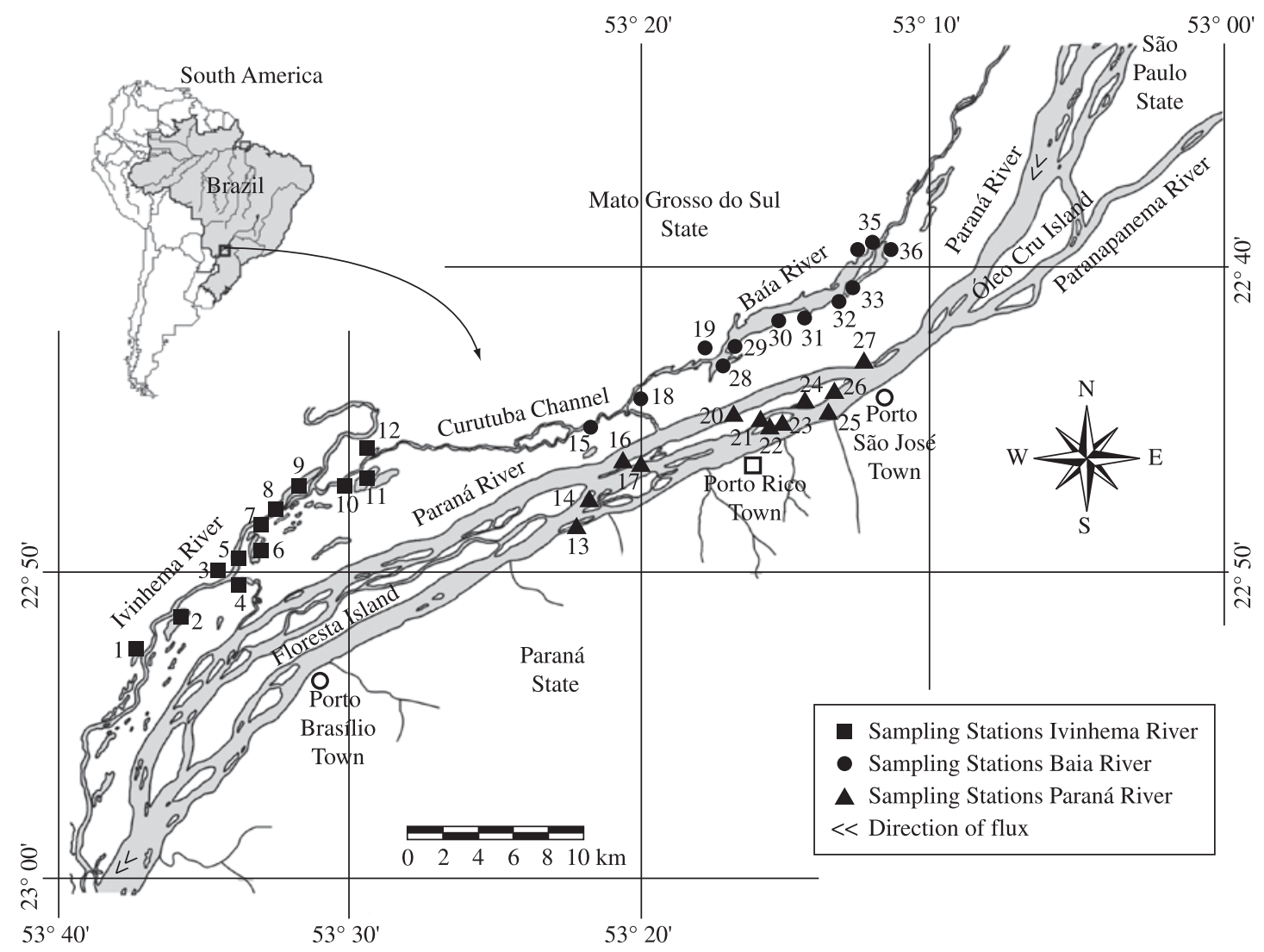

Figure 1. Location of the sampling stations on the Upper Paraná River floodplain. 
Table 1. Assemblage of fish species and their respective trophic guilds in the Upper Paraná River floodplain. Based on the analyses of Hahn et al. (2004) and Russo (2004).

\begin{tabular}{ll}
\hline Trophic guilds & \multicolumn{1}{c}{ Species } \\
\hline Detritivores & Apareiodon affinis, Cyphocharax modestus, Cyphocharax nagelii, Hypostomus spp., \\
& Loricariichthys platymetopon, Loricaria sp., Prochilodus lineatus, Rhinelepis aspera, \\
& Steindachnerina brevipinna, Steindachnerina insculpta \\
Herbivores & Astyanax schubarti, Leporinus lacustris, Schizodon altoparanae, Schizodon borellii \\
Insectivores & Astyanax altiparanae, Auchenipterus osteomystax, Brycon orbygnianus, Bryconamericus \\
& stramineus, Eigenmannia trilineata, Gymnotus inaequilabiatus, Gymnotus spp., Leporinus \\
& elongatus, Moenkhausia intermedia, Pimelodella gracilis, Pimelodella avanhandavae, \\
& Roeboides paranensis \\
Invertivores & Callichthys callichthys, Hoplosternum littorale, Iheringichthys labrosus, Satanoperca \\
& pappaterra, Trachydoras paraguayensis \\
Omnivores & Leporinus friderici, Leporinus obtusidens, Parauchenipterus galeatus, Pterodoras granulosus, \\
& Pimelodus maculatus \\
& Astronotus crassipinnis, Acestrorhynchus lacustris, Ageneiosus ucayalensis, Apteronotus sp., \\
& Crenicichla haroldoi, Catathyridium jenynsii, Crenicichla britskii, Cichla kelberi, Galeocharax \\
& knerii, Hoplias malabaricus, Hemisorubim platyrhynchos, Hoplerythrinus unitaeniatus, \\
& Pseudoplatystoma corruscans, Pinirampus pirinampu, Plagioscion squamosissimus, \\
& Rhaphiodon vulpinus, Sorubim lima, Serrasalmus maculatus, Serrasalmus marginatus, \\
& Salminus brasiliensis \\
& Aphyocharax anisitsi, Hypophthalmus edentatus
\end{tabular}
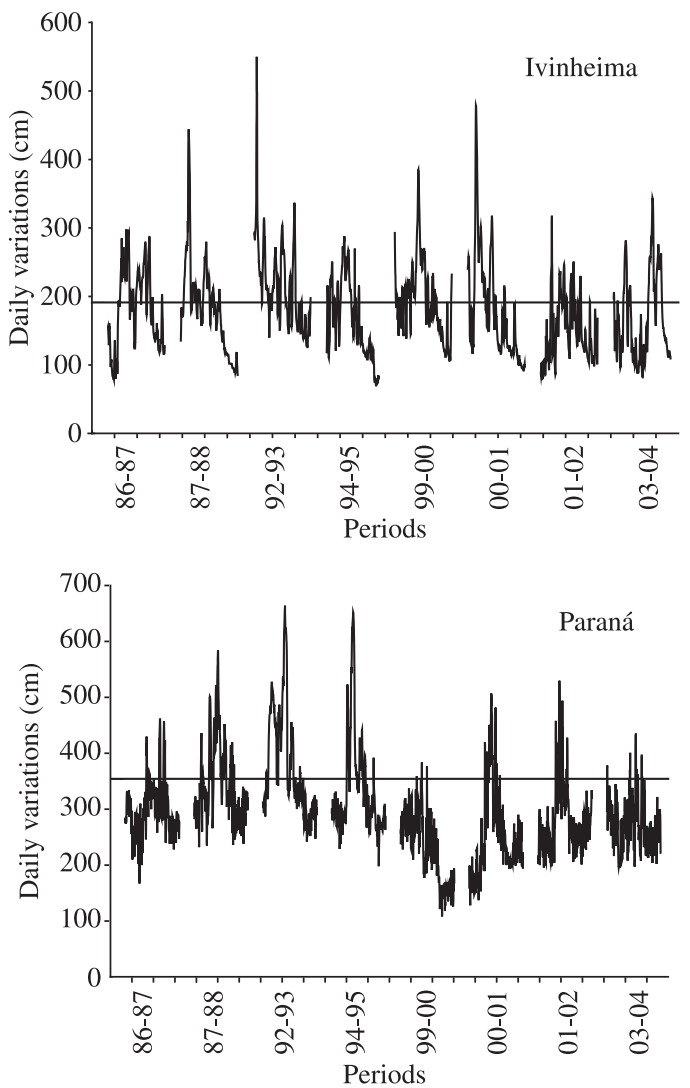

Figure 2. Daily variations in river levels during the fish sampling period. Horizontal lines show the threshold of the water level for river bank overflowing $(192 \mathrm{~cm}=$ Ivinheima River, Luz-Agostinho, 2008; 350 cm = Paraná River, Agostinho et al., 2004a).
In the Paraná River, the floods were also minor during the 1986-87, 2000-01, and 2003-04 cycles. Although the dry periods had some influence, especially in the year 2000-01, the closure of the Porto Primavera Dam (located about $40 \mathrm{~km}$ upstream) at the end of 1998 contributed to the occurrence of minor flooding during the two subsequent years. The Ivinheima, which has no reservoirs except for the extremes mentioned, had an annual hydrographic cycle that was less variable.

The attributes of the flood regime differed among the periods and sub-basins (Table 2). The duration of the annual floods in the Ivinheima River fluctuated between $15.0 \%$ (2001-02) and 63.3\% (1992-93) during the highwater period (November to May); whereas in the Paraná River, the duration of the floods varied between $1.3 \%$ (1999-00) and 38.1\% (1992-93) during the same period. In the Ivinheima River, the floods began earlier in the year and showed less inter-annual variation than in the Paraná River, especially after Porto Primavera dam. In both rivers, the annual maximum and mean levels were highest during the 1992-93 cycle. For the Paraná River, the lowest values of annual maximum and mean levels were recorded in 1999-2000. For the Ivinheima, this occurred in 1986-87 and 2001-02 for the annual maximum level, and in 2001-02 for the annual mean. The lowest values of the maximum levels were observed in 1994-95 for the Ivinheima, and in 1999-2000 for the Paraná.

\subsection{Variations in the body condition of the fish}

The analyses of variance applied to the mean annual values of the standardized residuals indicated significant interactions of the body condition for all the trophic guilds between the sub-basins and periods (Table 3). The absence 
Table 2. Values of the hydrological attributes in the two principal sub basins sampled on the Upper Paraná River floodplain, in each period $(\mathrm{CV}=$ coefficient of variation).

\begin{tabular}{|c|c|c|c|c|c|c|c|c|c|}
\hline \multirow[t]{2}{*}{ Sub basin } & \multirow[t]{2}{*}{ Attributes } & \multicolumn{8}{|c|}{ Periods } \\
\hline & & 86-87 & $87-88$ & $92-93$ & 94-95 & 99-00 & 00-01 & 01-02 & 03-04 \\
\hline \multirow[t]{7}{*}{ Ivinheima } & Duration (\%) & 47.3 & 41.5 & 63.3 & 29.0 & 21.1 & 46.9 & 15.2 & 42.2 \\
\hline & Beginning & 2/Dec. & 1/Nov. & 1/Oct. & 2/Oct. & 2/Dec. & 1/Nov. & 1/Nov. & 1/Dec. \\
\hline & Maximum (cm) & 298 & 444 & 550 & 367 & 383 & 479 & 318 & 344 \\
\hline & Mean (year-cm) & 184.0 & 184.0 & 226.9 & 172.2 & 162.0 & 203.5 & 142.1 & 179.3 \\
\hline & CV (\%)-year & 31.1 & 36.5 & 45.0 & 32.4 & 35.8 & 37.9 & 35.8 & 36.1 \\
\hline & Mean (flood, cm) & 191.3 & 233.7 & 211.5 & 178.7 & 131.0 & 226.7 & 244.1 & 149.9 \\
\hline & CV (\%)-flood & 32.6 & 27.1 & 53.9 & 34.0 & 27.4 & 23.9 & 31.6 & 35.6 \\
\hline \multirow[t]{7}{*}{ Paraná } & Duration (\%) & 10.0 & 36.8 & 38.1 & 25.2 & 1.3 & 8.3 & 13.9 & 7.6 \\
\hline & Beginning & 2/Feb. & 2/Nov. & $1 /$ Jan. & 2/Nov. & 2/Feb. & 2/Mar. & 2/Jan. & 1/Mar. \\
\hline & Maximum (cm) & 462 & 584 & 630 & 605 & 384 & 507 & & \\
\hline & Mean (year-cm) & 297.6 & 347.2 & 357.5 & 336.9 & 198.2 & 297.6 & 266.7 & 276.7 \\
\hline & CV (\%)-year & 16.6 & 20.9 & 26.9 & 19.9 & 26.9 & 14.4 & 27.0 & 16.4 \\
\hline & Mean (flood, cm) & 286.0 & 384.3 & 401.1 & 366.0 & 270.5 & 305.1 & 287.1 & 272.4 \\
\hline & CV (\%)-flood & 17.5 & 21.8 & 25.4 & 19.6 & 15.9 & 16.4 & 36.0 & 15.8 \\
\hline
\end{tabular}

Table 3. Results of the analysis of bifactorial variance applied to the standardized residuals generated from the regressions between the logarithms of total weight (Wt) and standard length (Ls) for each trophic guild.

\begin{tabular}{llll}
\hline \multirow{2}{*}{ Trophic guilds } & \multicolumn{3}{c}{ Factors } \\
\cline { 2 - 4 } & \multicolumn{1}{c}{ Locality (sub basin) } & \multicolumn{1}{c}{ Year } & \multicolumn{1}{c}{ Locality * year } \\
\hline Detritivores & $\mathrm{F}_{2.30950}=88.78 \mathrm{p}<0.001$ & $\mathrm{~F}_{7.30950}=704.11 \mathrm{p}<0.001$ & $\mathrm{~F}_{14.30950}=28.37 \mathrm{p}<0.001$ \\
Herbivores & $\mathrm{F}_{2.4943}=12.53 \mathrm{p}<0.001$ & $\mathrm{~F}_{7.4943}=57.05 \mathrm{p}<0.001$ & $\mathrm{~F}_{14.4943}=10.92 \mathrm{p}<0.001$ \\
Insectivores & $\mathrm{F}_{2.10855}=18.17 \mathrm{p}<0.001$ & $\mathrm{~F}_{7.10855}=120.12 \mathrm{p}<0.001$ & $\mathrm{~F}_{14.10855}=13.57 \mathrm{p}<0.001$ \\
Invertivores & $\mathrm{F}_{2.8146}=52.42 \mathrm{p}<0.001$ & $\mathrm{~F}_{7.8146}=137.98 \mathrm{p}<0.001$ & $\mathrm{~F}_{14.8146}=17.81 \mathrm{p}<0.001$ \\
Omnivores & $\mathrm{F}_{2.8621}=1.79 \mathrm{p}<0.001$ & $\mathrm{~F}_{7.8621}=107.30 \mathrm{p}<0.001$ & $\mathrm{~F}_{14.8621}=4.04 \mathrm{p}<0.001$ \\
Piscivores & $\mathrm{F}_{2.24813}=19.00 \mathrm{p}<0.001$ & $\mathrm{~F}_{7.24813}=17.53 \mathrm{p}<0.001$ & $\mathrm{~F}_{14.24813}=10.31 \mathrm{p}<0.001$ \\
Planktivores & $\mathrm{F}_{2.1731}=3.17 \mathrm{p}<0.001$ & $\mathrm{~F}_{6.1731}=23.27 \mathrm{p}<0.001$ & $\mathrm{~F}_{12.1731}=12.08 \mathrm{p}<0.001$ \\
\hline
\end{tabular}

of planktivorous species in the Paraná River in the second period made it impossible to use this period in the analysis.

The interaction between the factors (locality and period) made it difficult to evaluate, on a separate basis, the differences between the means found for the different sub-basins and periods. However, these results are to some degree expected in the context of this study, in that the different sub-basins showed distinct annual flood regimes during the time interval considered.

As a general pattern, means of body condition above the expected occurred during the year 2000. In all the trophic guilds, this pattern was more consistent in the Paraná and Baía rivers. In the Ivinheima River, although this tendency was also observed for some trophic guilds (detritivores, invertivores, omnivores, and planktivores), higher (but less extreme) values were recorded in other flood years, such as during 1986-87 (insectivores), 2002 (herbivores), and 2004 (piscivores).

In all three rivers, trends toward poorer body condition in the year of the highest flood (1992-93) were observed for the detritivores, insectivores, and invertivores.
For the herbivores in all the sub basins, the lowest values for body condition were obtained in the first cycle examined (1986-87); however, this was a dry year. During the study period, the piscivores did not show different patterns of variation among localities (Figure 3).

Until 1995, the temporal variations in body condition of the fish were quite similar among the three sub basins, with the different trophic guilds varying in a similar manner. Beginning in 2000, after the construction of the Porto Primavera Reservoir, representatives of these categories came to show divergent annual fluctuations.

\subsection{Correlations between attributes of the hydrological cycle and body condition}

Correlations (Pearson's $r$ and Spearman's $\rho$ ) between the attributes of the floods and the body condition of the fish were negative for the majority of the trophic guilds in all three localities (Table 4). Significant positive correlations were recorded for the attribute "beginning of the flood" between the detritivores of the Ivinheima and Baía rivers, demonstrating that the retardation of this at- 

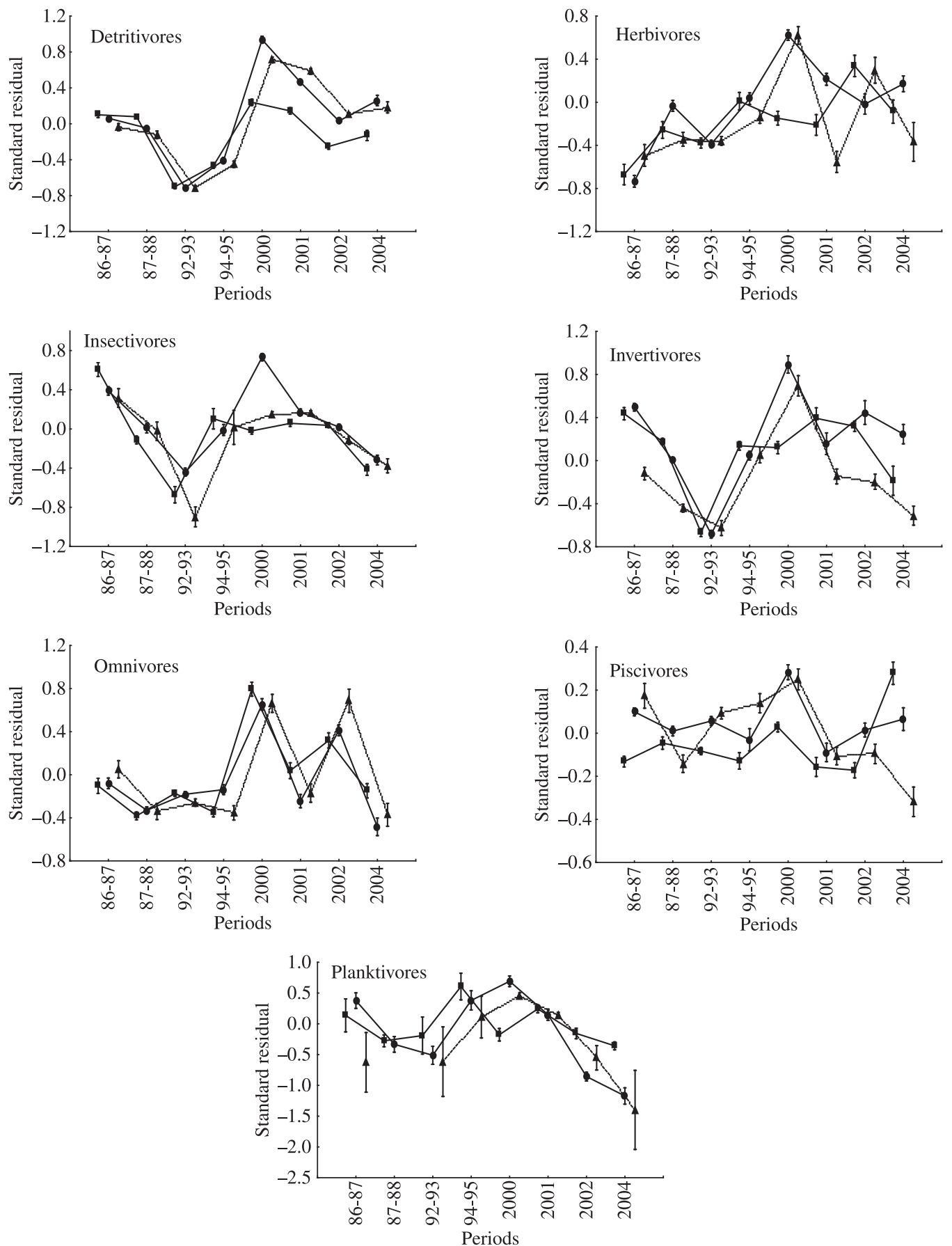

Figure 3. Mean values of the residuals of the ratio between the logarithms of total weight (Wt) and standard length (Ls) ( \pm standard error) of fish of different trophic guilds in the different sub basins and across sampling periods (Legend: $\mathbf{\bullet}=$ Ivinheima River, $\bullet=$ Baía River, and $\boldsymbol{\Delta}=$ Paraná River).

tribute had a positive effect on the weight gain of the individuals. There was also a significant positive correlation between the body condition of the herbivores and the coefficient of annual variation of the Paraná River level, demonstrating that the fluctuations in level favored weight gain in this group. This same attribute was, however, unfavorable for the body conditions of the insecti- vores and invertivores of the Ivinheima River. The variability of river levels during the flood period negatively affected the detritivores of the Ivinheima and Baía, as well as the invertivores of the Ivinheima.

The body condition of the detritivores was negatively correlated with the main attributes of the floods (duration, maximum level, annual mean level, and mean level 
during the floods) in both the Paraná and Baía rivers. A similar tendency was observed among the invertivores of the Baía sub-basin (Table 4).

The correlations between relative stomach weight (mean residuals of the relationship of stomach weight $\times$ total weight) and body condition (mean residuals of the relationship of total weight $\times$ length) were generally not statistically significant (Table 5). Except for the insectivores of the Paraná River, for which the increase in the mean values of stomach weight resulted in poorer body condition, no significant relationships were observed between these variables. Note that these correlations, though not significant, were positive only for the piscivores in all the sub basins.

\section{Discussion}

The body condition of fish can be inferred from the parameters of the length-weight ratio (Bagenal and Tesch, 1978), and reflects their general well-being. Called the condition factor or simply condition (Le Cren,

Table 4. Values of Pearson's and Spearman's correlations between the flood attributes and the relative weight of individuals (condition) for the different trophic guilds of the fish of the Upper Paraná River floodplain (for definitions of the attributes, see text). Values in bold = significant correlations.

\begin{tabular}{|c|c|c|c|c|c|c|c|}
\hline & Detritivores & Herbivores & Insectivores & Invertivores & Omnivores & Piscivores & Planktivores \\
\hline \multicolumn{8}{|c|}{ Ivinheima } \\
\hline Duration $(\%)$ & $-0.26 /-0.12$ & -0.81 & $-0.35 /-0.14$ & $-0.51 /-0.05$ & $-0.57 /$ & & -0.09 \\
\hline Beginning & $0.82 / 0.78$ & $-0.22 /-0.12$ & 0.50 & 0.49 & $0.50 / 0.55$ & $0.40 / 0.24$ & $-0.28 /-0.15$ \\
\hline Maximum $(\mathrm{cm})$ & $-0.32 /-0.07$ & $-0.22 /-0.28$ & $-0.64 /-0.52$ & $-0.57 /-0.43$ & $-0.21 /-0.26$ & $-0.13 / 0.19$ & $-0.10 /-0.14$ \\
\hline Mean (year-cm) & $-0.30 /-0.09$ & $-0.65 /-\mathbf{0 . 7 6}$ & $-0.43 /-0.28$ & $-0.55 /-0.07$ & $-0.47 /-0.48$ & $-0.03 / 0.05$ & $0.02 /-0.14$ \\
\hline CV (\%)-year & $-0.47 /-0.21$ & $-0.04 /-0.19$ & $-0.84 /-0.71$ & $-\mathbf{0 . 7 7 /}-0.38$ & $-0.01 /-0.21$ & $0.05 / 0.09$ & $-0.44 /-0.43$ \\
\hline Mean (flood, cm) & $-0.19 /-0.24$ & $0.13 /-0.02$ & $0.04 / 0.02$ & $0.19 / 0.45$ & $-0.35 /-0.14$ & $-0.66 /-0.67$ & $0.04 / 0.07$ \\
\hline & $-0.84 /-0.74$ & $-0.20 / 0.01$ & $-0.61 /-0.33$ & $-\mathbf{0 . 8 7 / - 0 . 6 2}$ & $-0.29 /-0.31$ & $0.08 / 0.28$ & $-0.18 /-0.24$ \\
\hline \multicolumn{8}{|c|}{ Baía } \\
\hline & & -0.26 & $-0.50 /-0.50$ & & & & \\
\hline Begir & $0.58 / \mathbf{0 . 7 5}$ & $0.09 / 0.24$ & $0.18 / 0.29$ & & $-0.09 /-0.16$ & $0.14 / 0.24$ & $-0.01 /-0.08$ \\
\hline Maximum (cm) & $-0.89 /-0.93$ & $-0.41 /-0.50$ & $-0.63 /-0.64$ & $-0.84 /-0.86$ & $-0.38 /-0.19$ & -0.60 & -0.1 \\
\hline Mean (year-cm) & $-0.87 /-0.81$ & $-0.62 /-0.64$ & $-0.68 /-0.60$ & $-0.88 /-0.86$ & $-\mathbf{0 . 7 2 / - 0 . 4 5}$ & $-0.67 /-0.38$ & $-0.21 /-0.07$ \\
\hline CV (\%)-year & $-0.14 /-0.43$ & $0.26 /-0.17$ & $0.30 /-0.10$ & $-0.43 /-0.05$ & $0.88 / 0.55$ & $0.74 / 0.24$ & $-0.62 /-0.10$ \\
\hline & $-0.79 /-0.83$ & $-0.30 /-0.55$ & $-0.53 /-0.60$ & $-0.85 /-0.93$ & $-0.40 /-0.36$ & $-0.40 /-0.64$ & $-0.04 /-0.17$ \\
\hline & $-0.44 /-\mathbf{0 . 7 6}$ & $-0.19 /-0.62$ & $-0.32 /-0.29$ & $-0.21 /-0$ & & $-0.23 /-$ & -0.4 \\
\hline \multicolumn{8}{|c|}{ Paraná } \\
\hline Duration (\%) & $-0.90 /-0.88$ & $-0.04 / 0.36$ & $-0.72 /-0.48$ & $-0.37 /-0.33$ & $-0.29 /-0.12$ & $0.32 / 0.12$ & $-0.09 /-0.14$ \\
\hline Beginning & $0.66 / 0.69$ & $-0.35 /-0.59$ & $0.18 / 0.28$ & $-0.07 / 0.01$ & $-0.11 / 0.10$ & $-0.43 /-0.11$ & $-0.17 /-0.05$ \\
\hline Maximum $(\mathrm{cm})$ & $-0.83 /-0.88$ & $-0.33 / 0.02$ & $-0.52 /-0.43$ & $-0.52 /-0.40$ & $-0.44 /-0.26$ & $0.07 /-0.12$ & $-0.01 /-0.07$ \\
\hline Mean (year-cm) & $-0.85 /-0.88$ & $-0.71 /-0.33$ & $-0.48 /-0.24$ & $-0.71 /-0.45$ & $-0.75 /-0.50$ & $-0.05 /-0.14$ & $-0.26 /-0.32$ \\
\hline CV (\%)-year & $-0.21 /-0.31$ & $0.75 / \mathbf{0 . 7 6}$ & $-0.41 /-0.48$ & $0.22 /-0.12$ & & & $0.20 / 0.11$ \\
\hline Mean (flood, cm) & $-0.83 /-0.81$ & $-0.30 /-0.14$ & $-0.60 /-0.36$ & $-0.40 /-0.48$ & $-0.52 /-0.31$ & $0.27 /-0.24$ & $0.09 / 0.01$ \\
\hline CV (\%)-flood & $-0.35 /-0.67$ & $0.30 / 0.29$ & $-0.34 /-0.36$ & $-0.29 /-0.31$ & $0.43 / 0.29$ & $-0.11 / 0.02$ & $-0.17 / 0.01$ \\
\hline
\end{tabular}

Table 5. Values of the correlations of Pearson (r) and Spearman ( $\rho$ ) between the relative stomach weights (residuals of the relationship We $\times \mathrm{Wt}$ ) and relative weight of the individuals (annual mean residuals of the relationship $\mathrm{Wt} \times \mathrm{Lt}$ ) for the different trophic guilds of the fish of the Upper Paraná River floodplain. Values in bold $=$ significant correlations, $*=$ no data.

\begin{tabular}{|c|c|c|c|c|c|c|}
\hline & \multicolumn{2}{|c|}{ Ivinheima } & \multicolumn{2}{|c|}{ Baía } & \multicolumn{2}{|c|}{ Paraná } \\
\hline & $\mathbf{r}$ & $\rho$ & $\mathbf{r}$ & $\rho$ & $\mathbf{r}$ & $\rho$ \\
\hline Detritivores & -0.201 & -0.095 & 0.301 & 0.119 & 0.331 & 0.381 \\
\hline Herbivores & -0.387 & -0.321 & 0.236 & 0.001 & 0.460 & 0.143 \\
\hline Insectivores & -0.076 & -0.286 & -0.467 & -0.179 & -0.849 & -0.771 \\
\hline Invertivores & -0.184 & 0.191 & -0.200 & -0.214 & -0.440 & -0.548 \\
\hline Omnivores & -0.376 & -0.571 & 0.225 & 0.071 & 0.208 & 0.024 \\
\hline Piscivores & 0.355 & 0.048 & 0.622 & 0.429 & 0.361 & 0.238 \\
\hline Planktivores & * & $*$ & -0.690 & -0.500 & $*$ & $*$ \\
\hline
\end{tabular}


1951), this factor is derived from the consideration that for a group of individuals of the same size, those weighing more are in better condition. Difficulties such as the strong correlation between the input parameters ( $\mathrm{a}$ and $\mathrm{b}$ of the length-weight relationship; Weisberg, 1985), the existence of allometry in the growth of many species (Braga, 1986), and the limitations in comparing different populations (Murphy et al., 1990) are some controversial points regarding the use of condition factors.

In this study, our choice to use the mean residuals, obtained from a general equation whose parameters were estimated for each species, resulted from our desire to compare the temporal trends of variation in the body conditions of fish belonging to different trophic guilds; this was done without intending precision. The body condition shown by fish is a result of many environmental factors, such as: physical and chemical variables of the water (Holmes and Yousen, 1994); biotic variables, such as intra- and interspecific interactions (competition, Wyttenbach and Senn, 1993; predation, Dannewitz and Petersson, 2001; diseases and parasitism, Machado et al., 2005; Hoffnagle et al., 2006); factors peculiar to all the species that comprise a guild (e.g., feeding strategies and tactics, reproduction, asymptotic size, Engelhard and Heino, 2006), the availability and quality of food (Luz-Agostinho et al., 2008), and the interactions among these variables (Asaeda et al., 2007). Therefore, a lack of consistency in some results is expected, seeing that some trophic guilds are composed of species with different reproductive strategies, dietary flexibility, or even tolerance to certain environmental conditions, such as fluctuations in oxygen or water levels.

The analysis of the results showed that the years with minor or even no floods resulted in mean values of body condition much superior to those of years with major floods, especially in the biotopes most affected by the closure of the Porto Primavera Reservoir (Paraná and Baía). Two hypotheses may explain this tendency: i) the lack of floods increases the availability of food of better nutritional value; and ii) the retention of nutrients and sediment behind the Porto Primavera Dam upstream produces an outflow that, during floods, causes the dilution of nutrients and reduction in drifting food organisms, intensifying the effects of the floods on the body condition of the fish.

Although the floods and water turbidity are important in spawning and survival and development in the initial life stages of fish - especially the migrators (Gomes and Agostinho, 1997; Agostinho et al., 2007) - these events cause profound changes to the habitats, increasing the dynamics of the watercourse and affecting energy expenditure (Ortlepp and Mürle, 2003) and changing the characteristics of the substrate, thus changing the benthic communities as a result (Petts, 1986). As a further result, these events reduce the primary productivity of phytoplankton (Train and Rodrigues, 1998; Rodrigues et al., 2002) and of submerged macrophytes (Padial and Thomaz, 2008; Thomaz et al., 2009), affecting the abundance and composition of the plankton (Velho et al., 2001; Ortlepp and Mürle, 2003) and the periphyton (Bielsa et al., 2003; Murakami et al., 2009). Thus, although the floods increase the availability of allochthonous food items from the flooded areas and drift, they reduce the autochtonous food supply. As a result of these processes, the floods change the nature of the available food and reduce its quality; these effects are in addition to the expected stress caused by oxygen depletion during the heterotrophic phase. During dry periods, the greater light penetration and substrate stability lead to primary and secondary productivity, resulting in good availability of more nutritious food items.

The second hypothesis can be substantiated by: i) the annual variations in body conditions of fish in the Ivinheima (which is not controlled by dams) were less pronounced than in the Paraná (directly affected by the retention of nutrients, sediments and drifting organisms caused by the dam upstream) and the Baía (moderately affected); and ii) the fish of the three rivers showed similar variations in annual mean condition before the closure of this reservoir, and these variations diverged in the subsequent period.

The generally negative correlation between flood attributes and nutritional condition (body condition) indicates the unfavorable effect of this event on the weight gain of representatives of different trophic guilds. This was particularly evident in the detritivores, for which all the relationships were found to be negative, except for the delay in the beginning of the floods (which had the same significance despite being positive). This group of fish includes species with different adaptations and strategies for food intake (Fugi et al., 1996; Fugi et al., 2001), including those that feed on the sediment, on periphyton or on rocky substrates. Together with the herbivores, this category has the most protein-limited diet (Bowen et al., 1995; Faria, 2007). These species show adaptations that allow them to ingest large amounts of food, including a digestive tract adapted to process the food, a mechanical stomach to crush algae with the aid of inorganic sediment, and/or a long intestine to increase absorption (Fugi et al., 1996; Fugi et al., 2001). Nevertheless, the resources ingested by this group show a wide range of spatial and temporal variation in nutritional value, and although these resources are apparently unlimited, detritivores show a high degree of selectivity, seeking to ingest more protein-rich material (Bowen, 1987). This explains their predominance in fish biomass in tropical rivers (Lowe-McConnell, 1999). Periphytic algae or algae that concentrate in the upper sediment layers are important components in the nutritional quality of the diet of detritivores, and they are affected by major floods as much by the transport processes (carried by the strongest currents) as by deposition on the sediment (Bowen, 1987). In the case of the Paraná River sub basin, the second process was obviously more important.

The variability in river level, measured using the coefficient of annual variation, showed that this attribute 
acted favorably only on the body condition of the herbivores of the Paraná River, probably due to the frequency of access to areas with vegetation along the banks, especially grasses. This variability had a negative effect on some other trophic guilds (detritivores, insectivores, and invertivores, especially in the Ivinheima). It is nevertheless expected that medium-scale fluctuations will positively affect the availability of food for fish, because they bring in allochthonous resources. However, the results showed that there was no significant correlation between the mean stomach weight (mean residuals of the relationship: stomach weight $\times$ total weight) and the body condition, except for the insectivores of the Paraná River. The negative relationship found for this group indicates that the food taken during the flood period was of poorer nutritional quality and/or difficult to digest, remaining longer in the stomach. It is equally appropriate to emphasize that only the piscivores showed positive correlations between feeding activity and body condition, although these were not significant. This must be attributed to the lower variability in the nutritional value of the resources consumed during the years and in the sub-basins considered, independently of the flood regime. The detritivores, herbivores and omnivores showed negative correlations in the Ivinheima River, and positive correlations in the Paraná. The food used by these trophic guilds have lower energy and protein content (Faria, 2007), and the trends shown by the results confirm that the nutritional value of the resources eaten by these fish shows high spatial (Bowen, 1987) and temporal variation. The capability to alter the diet (while more characteristic of omnivores) can be seen in fish of other trophic guilds in floodplain environments (Hahn et al., 2004). Thus, although many species of fish are omnivores during the entire year, others reveal themselves to be omnivorous when their main food source becomes less abundant (Bowen, 1995).

It is thus concluded that minor floods or no floods, although they may be responsible for recruitment failures of new individuals into the populations or the high mortality of juveniles (Agostinho et al., 2004b), have a positive impact on body condition. These floods affect fish of all trophic guilds to different degrees, independently of feeding intensity. This impact is weaker in waterbodies that are free of dams.

Good body conditions increase the probability that individuals will carry out reproductive migrations (Engelhard and Heino, 2006), increase fecundity, and also increase the diameter and viability of the eggs (Thorsen et al., 2006), positively affecting the fitness. On the other hand, major floods are known to be important for reproduction and initial development, particularly for migratory species, and also contribute to their reproductive success (Agostinho et al., 2004a). This apparently paradoxical situation can be considered as an adaptation of the fish fauna (especially the migrators) to improve fitness, because drought years are naturally recurrent phenomena (as are major floods). Therefore, alternations between drought and flood years would be highly significant events for the species conservation.

Acknowledgements - This study was supported by the "Long-Term Ecological Research" (PELD) program of CNPq. Angelo Antonio Agostinho and Norma Segatti Hahn has been continuously supported by $\mathrm{CNPq}$ productivity fellowships. Fabiane Abujanra was supported by CNPq graduate fellowships. Authors are grateful to the field team from Nupelia and PEA (Universidade Estadual de Maringá) by logistic support during sampling and Jaime Luiz Lopes Pereira for illustrations.

\section{References}

AGOSTINHO, AA., GOMES, LC., VERÍSSIMO, S. and OKADA, EK., 2004a. Flood regime and fish: effects on spawning, recruitment and attributes of the assemblages in the Upper Paraná River floodplain. Reviews in Fish Biology and Fisheries, vol. 14, no. 1, p. 11-19.

AGOStinho, AA., PELICICE, FM., PETRY, AC., GOMES, LC. and JÚLIO Jr., HF., 2007. Fish diversity in the upper Paraná River basin: habitats, fisheries, management and conservation. Aquatic Ecosystem Health \& Management, vol. 10, no. 2, p. $174-186$.

AGOSTINHO, AA., THOMAZ, SM. and GOMES, LC., 2004b. Threats for biodiversity in the floodplain of the upper Paraná River: effects of hydrological regulation by dams. Ecohydrology \& Hydrobiology, vol. 4, no. 3, p. 255-268.

ALMEIDA, VLL., HAHN, NS. and VAZZOLER, AEAM., 1997. Feeding patterns in five predatory fishes of the high Paraná River floodplain (PR, Brazil). Ecology of Freshwater Fish, vol. 6, no. 3, p. 123-133.

ASAEDA, ST., MANATUNGE, J. and TAKESHI, F., 2007. The effects of predation risk and current velocity stress on growth, condition and swimming energetics of Japanese minnow (Pseudorasbora parva). Ecological Research, vol. 22, no. 1, p. 32-40.

BAGENAL, TB. and TESCH, FW., 1978. Age and growth. In BAGENAL, TB. (Ed.). Methods for assessment of fish production in fresh water. Oxford: Blackwell. p. 101-136.

BIELSA, S., FRANCISCO, P., MASTRORILLO, S. and PARENT, JP., 2003. Seasonal changes of periphytic nutritive quality for Sicyopterus lagocephalus (Pallas, 1770) (Gobiidae) in three streams of Reunion Island. Annales de LimnologieInternational Journal of Limnology, vol. 39, no. 2, p. 115-127.

BOWEN, SH., 1987. Composition and nutritional value of detritus. In MORIARTY, DJW. and PULLIN, RSV. (Eds.). Detritus and microbial ecology in aquaculture. Philippines: Manila. p. 192-216.

BOWEN, SH., LUTZ, EV. and AHLGREN, MO., 1995. Dietary protein and energy as determinants of food quality: trophic strategies compared. Ecology, vol. 76, no. 3, p. 899-907.

BRAGA, FMS., 1986. Estudo entre fator de condição e relação peso/comprimento para alguns peixes marinhos (Study between condition factor and length/weight relation for some marine fishes). Revista Brasileira de Biologia = Brazilian Journal of Biology, vol. 46, no. 2, p. 339-346.

DANNEWITZ, J. and PETERSSON, E., 2001. Association between growth, body condition and anti-predator behaviour 
in maturing and immature brown trout parr. Journal of Fish Biology, vol. 59, no. 4, p. 1081-1091.

ENGELHARD, GH. and HEINO, M., 2006. Climate change and condition of herring (Clupea harengus) explain long-term trends in extent of skipped reproduction. Oecologia, vol. 149, no. 4, p. 593-603.

FARIA, ACEA., 2007. Fontes de energia, posição trófica e digestibilidade do alimento de peixes da planície de inundação do alto rio Paraná. Maringá: Universidade Estadual de Maringá - UEM. 58 p. Tese de Doutorado.

FUGI, R., AGOSTINHO, AA. and HAHN, NS., 2001. Trophic morphology of five benthic-feeding fish species of a tropical floodplain. Revista Brasileira de Biologia = Brazilian Journal of Biology, vol. 61, no. 1, p. 27-33.

FUGI, R., HAHN, NS. and AGOSTINHO, AA., 1996. Feeding styles of five species of bottom-feeding fishes of the high Paraná River. Environmental Biology of Fishes, vol. 46, no. 3, p. 297-307.

GOMES, LC. and AGOSTINHO, AA., 1997. Influence of the flooding regime on the nutritional state and juvenile recruitment of the curimba, Prochilodus scrofa, Steidachner, in upper Paraná River, Brazil. Fisheries Management and Ecology, vol. 4, no. 4, p. 263-274.

HAHN, NS., FUGI, R. and ANDRIAN, IF., 2004. Trophic ecology of the fish assemblages. In THOMAZ, SM., AGOSTINHO, AA. and HAHN, NS. (Eds.). The Upper Paraná River and its floodplain: physical aspects, ecology and conservation. Leiden: Backhuys Publishers. p. 247-269.

HOFFNAGLE, TL., CHOUDHURY, A. and COLE, RA., 2006. Parasitism and body condition in humpback chub from the Colorado and Little Colorado Rivers, Grand Canyon, Arizona. Journal of Aquatic Animal Health, vol. 18, no. 3, p. 184-193.

HOLMES, JA. and YOUSON, JH., 1994. Fall condition factor and temperature influence the incidence of metamorphosis in Sea Lampreys, Petromyzon marinus. Canadian Journal of Zoology, vol. 72, no. 6, p. 1134-1140.2

JUNK, WJ. and WANTZEN, KM., 2004. The flood pulse concept: new aspects, approaches and applications - an update. In Proceedings of the Second International Symposium on the Management of Large Rivers for Fisheries, February 11-14, 2003. Bangkok: FAO Regional Office for Asia and the Pacific; RAP Publication. p.117-140.

JUNK, WJ., 1980. Áreas inundáveis: um desafio para limnologia. Acta Amazônica, vol. 10, no. 4, p. 775-795.

JUNK, WJ., BAYLEY, PB. and SPARKS, RE., 1989. The flood pulse concept in river-floodplain systems. Canadian Special Publications in Fisheries and Aquatic Sciences, vol. 106, p. 110-127. Trabalho apresentado no International Large River Symposium.

Le CREN, ED., 1951. The length-weight relationship and seasonal cycle in gonad weight and condition in the perch (Perca fluviatilis). Journal of Animal Ecology, vol. 20, no. 2, p. 201-219.

LOWE-McCONNELL, RH., 1999. Estudos ecológicos de comunidades de peixes tropicais. São Paulo: EDUSP. 393p.

LUZ-AGOSTINHO, KD., AGOSTINHO, AA., GOMES, LC. and JÚLIO Jr., HF., 2008. Influence of flood pulses on diet composition and trophic relationships among piscivorous fish in the upper Paraná River floodplain. Hydrobiologia, vol. 607, no. 1 , p. 187-198.

LUZ-AGOSTINHO, KD., AGOSTINHO, AA., GOMES, LC., JÚLIO Jr., HF. and FUGI, R., 2009. Effects of flooding regime on the feeding activity and body condition of piscivorous fish in the upper Paraná River floodplain, Brazil. Revista Brasileira de Biologia = Brazilian Journal of Biology, vol. 69, no. (2 suppl), p. $469-479$

MACHADO, PM., TAKEMOTO, RM. and PAVANELLI, GC., 2005. Diplostomum (Austrodiplostomum) compactum (Lutz, 1928) (Platyhelminthes, Digenea) metacercariae in fish from the floodplain of the Upper Paraná River, Brazil. Parasitology Research, vol. 97, no. 6, p. 436-444.

MARÇAL-SIMABUKU, MA. and PERET, AC., 2002. Alimentação de peixes (Osteichthyes, Characiformes) em duas lagoas de uma planície de inundação brasileira da bacia do rio Paraná. Interciencia, vol. 27, no. 6, p. 299-306.

MURAKAMI, EA., BICUDO, DC. and RODRIGUES, L., 2009. Periphytic algae of the Garças Lagoon, Upper Paraná River floodplain: comparing the years 1994 and 2004. Revista Brasileira de Biologia = Brazilian Journal of Biology, vol. 69, no. (2 suppl), p. 459-468.

MURPHY, BR., BROWN, ML. and SPRINGER, TA., 1990. Evaluation of the relative weight (Wr) index, with new applications to walleye. North American Journal of Fish Management, vol. 10, no. 1, p. 85-97.

NEIFF, JJ., 1990. Ideas para la interpretación ecologica del Paraná. Interciencia, vol. 15, no. 6, p. 424-441.

ORTLEPP, J. and MÜRLE, U., 2003. Effects of experimental flooding on brown trout (Salmo trutta fario L.): the River Spöl, Swiss National Park. Aquatic Sciences, vol. 65, no. 3, p. $232-238$

PADIAL, AA. and THOMAZ, SM., 2008. Prediction of the light attenuation coefficient through the Secchi disk depth: empirical modeling in two large Neotropical ecosystems. Limnology, vol. 9 , no. 2, p. 143-151.

PETTS, GE., 1986. Water quality characteristics of regulated Rivers. Progress in Physical Geography, vol. 10, no. 4, p. $492-516$

RODRIGUES, LC., TRAIN, S., ROBERTO, MC. and PAGIORO, TA., 2002. Seasonal fluctuation of some limnological variables on a floodplain lake (Patos lagoon) of the Upper Paraná River, Mato Grosso do Sul State, Brazil. Brazilian Archives of Biology and Technology, vol. 45, no. 4, p. 499-513.

RUSSO, MR., 2004. Ecologia trófica da ictiofauna de pequeno porte, em lagoas isoladas da planície de inundação do alto rio Paraná, Brasil. Maringá: Universidade Estadual de Maringá. 38p. Tese de Doutorado.

THOMAZ, SM., CARVALHO, P., PADIAL, AA. and KOBAYASHI, JT., 2009. Temporal and spatial patterns of aquatic macrothyte diversity in the Upper Paraná River floodplain. Revista Brasileira de Biologia = Brasilian Journal of Biology. vol. 69, no. (2 suppl), p. 617-625.

THOMAZ, SM., PAGIORO, TA., BINI, LM., ROBERTO, MC. and ROCHA, RRA., 2004. Limnological characterization of the aquatic environments and the influence of hydrometric levels. In THOMAZ, SM., AGOSTINHO, AA. and HANH, NS. (Eds.). The upper Paraná river and its floodplain: physical aspects, 
ecology and conservation. Leiden: Backhuys Publishers. p. 75-102.

THORSEN, A., MARCHALL, CT. and KJESBU, OS., 2006. Comparison of various potential fecundity models for northeast Arctic cod Gadus morhua, L. using oocyte diameter as a standardizing factor. Journal of Fish Biology, vol. 69, no. 6, p. $1709-1730$.

TRAIN, S. and RODRIGUES, LC., 1998. Temporal fluctuations of the phytoplankton community of the Baía River, in the upper Paraná River floodplain, Mato Grosso do Sul, Brazil. Hydrobiologia, vol. 361, p. 125-134.
VELHO, LFM., LANSAC-TÔHA, FA., BONECKER, CC., BINI, LM. and ROSSA, DC., 2001. The longitudinal distribution of copepods in Corumbá Reservoir, State of Goiás, Brazil. Hydrobiologia, vol. 453-454, p. 385-391.

WEISBERG, S., 1985. Applied linear regression. 2 ed. New York: John Wiley \& Sons. 324p.

WYTTENBACH, A. and SENN, DG., 1993. Intertidal habitat: does the shore level affect the nutritional condition of the shanny (Lipophrys pholis, Teleostei, Blenniidae)? Cellular and Molecular Life Sciences (CMLS), vol. 49, no. 8, p. $725-728$. 